\title{
NILAI TAMBAH DAN STRATEGI PEMASARAN KOPI BUBUK AROMA
}

\section{ADDED VALUE AND MARKETING STRATEGY OF GROUND COFFEE AROMA}

\author{
Melisa Ayu Oktariza, Nusril, Ketut Sukiyono $\square$ \\ ${ }^{1}$ Jurusan Sosial Ekonomi Pertanian, Fakultas Pertanian, Universitas Bengkulu \\ Corresponding author: ksukiyono@unib.ac.id
}

\begin{abstract}
ABSTRAK
Tujuan dari penelitian ini adalah (1) untuk mengetahui besarnya nilai tambah yang dihasilkan dari pengolahan biji kopi menjadi kopi bubuk aroma. (2) untuk menganalisis Strategi Bauran pemasaran apa yang paling diprioritaskan untuk meningkatkan volume penjualan kopi bubuk. (3) untuk mengetahui alternativ strategi pemasaran apa yang tepat dari bauran pemasaran yang terpilih. Metode yang digunakan adalah metode nilai tambah hayami dan analytical hierarchy process (AHP). Hasil penelitian menunjukan bahwa nilai tambah yang diperoleh pada proses ini untuk kemasan biasa adalah sebesar 8.065 dengan rasio nilai tambah sebesar $26,52 \%$ sedangkan nilai tambah untuk plastik alumunium foil sebesar 10.035 dengan rasio nilai tambah sebesar 27,50 \%. Pada kriteria ini yang menjadi prioritas pertama adalah kondisi finansial perusahaan dengan bobotnya adalah sebesar 0,334 sedangkan alternatifnya yang paling diprioritaskan adalah strategi produk dengan bobot sebesar 0,345. Modal menjadi prioritas yang paling diutamakan dalam stretegi produk dengan bobot sebesar 0,667 . lalu menjadi prioritas pada alternatif produk adalah mendeversifikasikan ukuran produk dengan bobot sebesar 0,262.
\end{abstract}

Kata Kunci : Nilai Tambah; Srategi Pemasaran; Analisis Hirarki Proses (AHP).

\section{ABSTRACT}

The purpose of this study are (1) to know the value added resulting from the processing of coffee beans into ground coffee aroma. (2) to analyze what the marketing mix strategy that prioritized to increase the sales volume of ground coffee. (3) to know what the alternative marketing strategy that right of any marketing mix. The method used is the valueadded method Hayami and analytical hierarchy process (AHP). The results showed that the value added obtained in this process for regular packaging amounted to 8.065 with value added ratio of $26,52 \%$, while the value added to the plastic foil ratio amounted to 10.035 with an added value of $27,50 \%$. On this criterion that the first priority is the financial condition of the company with its weight amounted to 0.334 while the subcriteria most priority is the product strategy with a weight of 0.345. Capital is a priority of the most preferred in stretegi products with a weight of 0.667. then became a priority to the alternative product is mendeversifikasikan size product with a weight of 0.262 .

Keywords :Value Added; Marketing Strategy; Analitycal Hierarechy Process(AHP). 


\section{PENDAHULUAN}

Kopi bubuk merupakan minuman yang sangat umum dan tersebar luas di sekitar kita. Keberhasilan dalam perusahaan untuk menyampaikan produk ke konsumen akan memerlukan pedagang penyalur, berupa lembaga-lembaga pemasaran agar produk cepat sampai ke konsumen. Peranan lembaga pemasaran sangat diperlukan oleh perusahan untuk memasarkan produk yang dihasilkan. Penggilingan kopi beras menjadi kopi bubuk dapat dilakukan oleh petani dan pihak industri/pabrik. Pengolahan oleh petani biasanya lebih tradisional, karena menggunakan alat yang sederhana. Sedangkan pada industri atau pabrik, penggilingan dilakukan secara modern Buah kopi yang berbentuk biji tersebut, akan mengalami proses produksi di dalam pabrik atau industri yang akan menjadi nilai tambah dari biji kopi menjadi bubuk kopi.

Meningkatnya permintaan dan persaingan kopi bubuk pada gilirannya menyebabkan para pengusaha kopi terus berusaha untuk meningkatkan nilai tambah (Value Added) hasil perkebunan kopi melalui pengolahan lebih lanjut. Dalam rangka menciptakan produk yang bernilai ekonomis maka keseimbangan antara industri dan pertanian berkaitan baik dari segi pendapatan usahatani, nilai tambah maupun lembaga-lembaga yang terlibat dalam pemasaran produk dalam rangka mensukseskan otonomi daerah (Maimun,2009). Lebih lanjut, berkembangnya industri kopi bubuk mengakibatkan terjadinya peningkatan persaingan antara industri kecil, menengah dan besar. Ada 16 produk kopi bubuk yang beredar di Kota Bengkulu diantaranya adalah UD. Riska, Aroma, Super Enak, Cangkir, Bintang baru, Cahaya baru, Yunita, 1001, Layar, Bola dunia, Mitra, Purnamaa, Selatan, Idola, dan Sari rasa (Desperindag, 2015). Peningkatan persaingan ini juga dialami kopi bubuk Aroma. Perusahaan ini merupakan salah satu indrustri kecil kopi bubuk yang ada di Kota Bengkulu. Industri kecil pada umumnya memiliki kekuatan tawar menawar dan kemampuan untuk melakukan promosi produk yang rendah, sehingga industri kecil tidak mampu memasarkan produknya secara optimal dan pada akhirnya menyebabkan penurunan penjualan. Salah satu industri kecil yang mengelolah biji kopi menjadi kopi bubuk adalah kopi Bubuk Aroma.

Kopi bubuk aroma belum mampu dipasarkan di seluruh wilayah Kota Bengkulu. Hal ini disebabkan oleh, kurangnya pemasaran karena kopi bubuk aroma ini hanya memasarkan produknya dipasar Panorama saja. Selain itu banyaknya pesaing-pesaing di wilayah Kota Bengkulu membuat kopi bubuk ini 
sulit untuk memasarkan produknya karena untuk memasuki pasar lainnya sudah terjanggal oleh produk lain. Melihat banyaknya pesaing pada produk kopi bubuk di kota Bengkulu, maka produk kopi Aroma harus mampu besaing dengan meningkatkan kualitasnya.Hal ini yang menjadi latar belakang untuk melakukan penelitian mengenai strategi pemasaran yang tepat untuk kemajuan produk kopi bubuk Aroma di Kota Bengkulu, sebab industri kecil saat ini bukan hanya menghadapi masalah bagaimana memproduksi suatu barang untuk mendapatkan nilai tambah, tetapi yang paling penting adalah bagaimana cara memasarkan hasil produksi tersebut. Oleh sebab itu dari itu peneliti ingin mencari tahu lebih lanjut mengenai nilai tambah dari biji kopi menjadi kopi bubuk dan menganalis lebih lanjut strategi pemasaran pada produk kopi bubuk Aroma.

Tujuan penelitian ini untuk menganalisis besarnya nilai tambah dari usaha pengolahan biji kopi menjadi kopi bubuk Aroma di Kota Bengkulu, menganalisis Bauran Strategi pemasaran yang paling diprioritaskan untuk meningkatkan volume penjulan kopi bubuk Aroma di Kota Bengkulu, dan menganalisis alternatif srategi pemasaran dari bauran pemasaran yang terpilih.

\section{METODE PENELITIAN}

\section{Analisis Deskripsi}

Analisis Deskripsi adalah analisis yang menggambarkan keadaan dari suatu objek penelitian, yang digunakan untuk menjawab permasalahan pertama dan kedua dalam penelitian ini. Untuk keperluan ini peneliti melakukan wawancara dengan pengusaha tentang profil perusahaan dan bagaimana pengusaha menghadapi masalah yang ada.

\section{Analisis Nilai Tambah Nayami}

Menurut Tarigan (2004) Nilai tambah didapatkan dari nilai produk akhir dikurangi biaya antara (intermediate cost) yang terdiri dari biaya bahan baku dan bahan penolong dalam melakukan proses produksi (besarnya nilai dari proses pengolahan).

\section{Metode Analytical Hierarchy Process}

\section{(AHP)}

Dalam menentukan prioritas prioritas strategi pemasaran akan dianalisis dengan metode analisis AHP (Analytical Hierarchy Process). Dengan metode AHP diawali dengan pengumpulan data dan menyusun struktur Hierarki. Dalam penelitian ini, metode analisis data menggunakan software Expert Choice 11 dan Microsoft Excel.

Adapun prosedur dalam penggunaan metode AHP adalah sebagai berikut:

1. Menyusun hirarki yang digunakan untuk menguraikan permasalahan dalam mengidentifikasi faktor dalam 
pemilihan Strategi pemasaran kopi

bubuk Aroma yang diprioritaskan dan kemudian menyusun matriks banding berpasangannya.

2. Menentukan nilai tentang kepentingan relatif dari dua elemen melalui kuisioner berdasarkan input dari para pakar/ahli (expert) menggunakan nilai skala banding berpasangan

Nilai perbandingan A dengan $B$ adalah 1 (satu) dibagi dengan nilai perbandingan B dengan A. Pendapat para ahli (expert) yang konsisten kemudian akan digabungkan dengan menggunakan rata-rata geometrik (Marimin, 2004):

$$
\overline{\mathbf{X}}_{\mathbf{G}}=\sqrt[n]{n}{ }_{1} \mathrm{x} \mathrm{n}_{2} \mathrm{x} \ldots \ldots . \mathrm{x} \mathrm{n}_{\mathrm{n}}
$$

Ket : $\overline{\mathbf{X}}_{\mathbf{G}}=$ Rata-rata geometri

$\mathrm{n}=$ jumlah responden

$\mathrm{n}_{1}=$ Penilaian responden ke- 1

$$
\begin{aligned}
\mathrm{n}_{2} & =\text { Penilaian responden ke- } 2 \\
\mathrm{n}_{\mathrm{n}} & =\text { Penilaian responden ke- } \mathrm{n}
\end{aligned}
$$

3. Melakukan sintesis hasil dari penilaian yang telah dilakukan yaitu mengukur bobot prioritas setiap elemen tersebut dengan dasar persepsi seorang ahli (expert).

4. Melakukan pengecekan konsistensi yang berguna untuk mengidentifikasikan kemungkinankemungkinan kesalahan dalam penilaian sebagaimana adanya terjadinya inkonsistensi dalam penilaian. Jika tidak memenuhi syarat dengan nilai Rasio Inkonsistensi (CR) $<0,1$ maka penilaian harus diulang kembali.

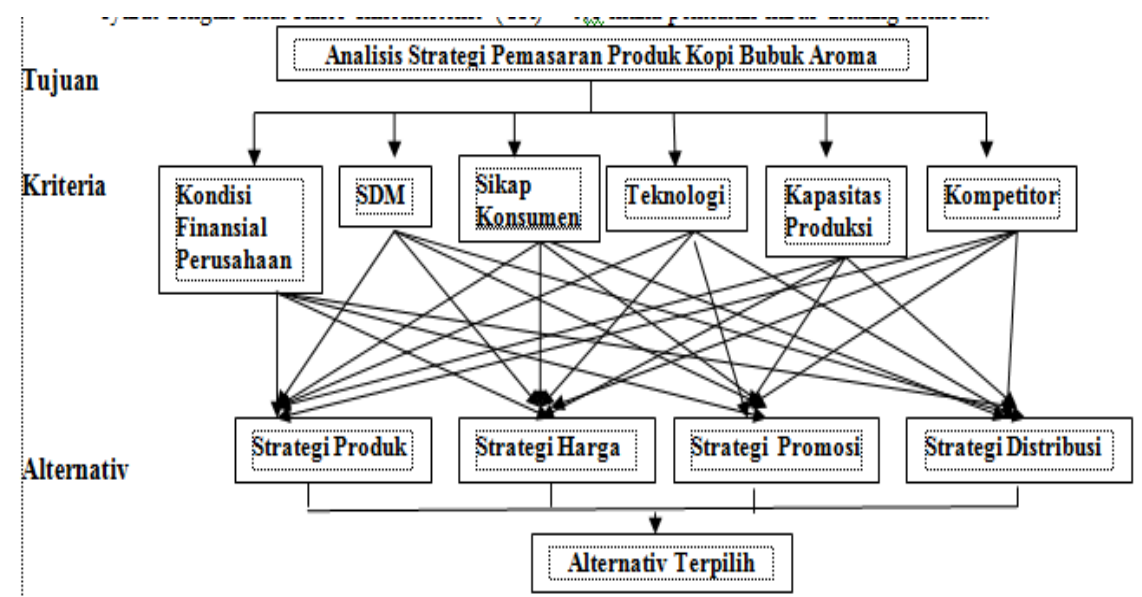

Gambar 1. Struktur Hirarki Strategi Pemasaran Produk Kopi Bubuk Aroma 


\section{HASIL DAN PEMBAHASAN}

Karakteristik responden yang diteliti dalam penelitian analisis nilai tambah dan strategi pemasaran kopi bubuk ini adalah responden untuk nilai tambah 1 orang dan strategi pemasaran 8 orang. Karasteristik nilai tambah yang diamati meliputi umur,pekerjaan, tingkat pendidikan, jumlah anggota keluarga, dan pengalaman mengelolah kopi bubuk. Karasteristik untuk strategi pemasaran adalah nama, jabatan, dan alamat.

\section{Analisis Nilai Tambah Pengolahan Biji}

\section{Kopi Menjadi Kopi Bubuk}

Analisis nilai tambah pada proses pengolahan biji kopi menjadi kopi bubuk berpijak pada tahapan proses yang dilakukan oleh pengolah kopi bubuk aroma selama periode produksi $3 \mathrm{x}$ dalam satu minggu. Perhitungan nilai tambah dilakukan dengan metode nilai tambah hayami antara nilai tambah kopi bubuk kemasan alumunium foil dan kemasan plastik biasa. Kegiatan pengolahan biji kopi menjadi kopi bubuk mampu memberikan nilai tambah bagi pengolah kopi bubuk. Dalam analisis nilai tambah ini dapat diketahui besarnya nilai tambah, imbalan tenaga kerja, imbalan modal, serta keuntungan pengolahan.

Analisis nilai tambah tersebut diperoleh dari kemasan plastik biasa dan kemasan Alumunium Foil. Pengelolah menggunakan bahan baku biji kopi untuk kemasan biasa sebanyak $270 \mathrm{~kg}$ per minggu dan kemasan alumunium foil sebanyak $90 \mathrm{~kg}$ per minggu. Untuk membuat bubuk kopi, dengan harga biji kopi kedua kemasan itu adalah sebesar Rp.20.000 per kg. Pengusaha kopi bubuk mampu memproduksi kopi bubuk kemasan biasa sebanyak $207 \mathrm{~kg}$ per minggu dengan harga jual sebesar 40.000 per $\mathrm{kg}$. Sedangkan untuk kemasan alumunium foil didapatkan hasil sebesar $69 \mathrm{~kg}$ per minggu dengan harga jualnya sebesar 48.000 per $\mathrm{kg}$.

Faktor konversi didasarkan pada besarnya perolehan output dari $1 \mathrm{~kg}$ bahan baku biji kopi. Faktor konversi dari kedua kemasan yang diperoleh dari pengolahan kopi bubuk ini adalah 0,76 artinya setiap 1 $\mathrm{kg}$ biji kopi akan menghasilkan kopi bubuk sebanyak 0,76 kg kopi bubuk.Tenaga kerja yang digunakan dalam proses pengolahan biji kopi menjadi kopi bubuk menggunakan tenaga kerja dalam keluarga dan luar keluarga. Dalam pengolahan ini tenaga kerja yang tercurah dari kedua kemasan adalah sebesar 21 JOK dengan upah kedua kemasan tersebut sebesar Rp. 19.286 perJOK. Tenaga kerja yang digunakan pada pengolahan kopi bubuk ini adalah laki-laki sedangkan untuk pengemasan perempuan. Koefisien tenaga kerja merupakan perbandingan dari jumlah jam kerja dibagi input Berdasarkan tabel 
diatas nilai koefisien pada kemasan alumunium foil adalah sebesar 0,23 artinya bahwa setiap $1 \mathrm{~kg}$ biji kopi untuk kemasan alumunium foil dibutuhkan curahan tenaga kerja sebesar 0,23 JOK. Untuk kemasan alumunium foil koefisien didapat adalah 0,07 yang artinya bahwa kg biji kopi untuk kemasan biasa dibutuhkan curahan tenaga kerja sebesar 0,07 JOK

Harga bahan baku kedua kemasan itu memeiliki harga yang sama (input) dari 1 kg biji kopi adalah Rp. 20.000/kg. Dengan harga kemasan biasa dipasaran adalah Rp. 40.000/kg dan kemasan alumunium foil 48.000 . Selain biaya bahan baku dan biaya tenaga kerja, pengusaha juga mengeluarkan biaya input lain. Besarnya biaya input lain yang dikeluarkan untuk pengolahan satu kilogram biji kopi menjadi kopi bubuk untuk kemasan alumunium foil adalah sebesar Rp. 6445 sedangkan untuk kemasan biasa adalah sebesar 2.335 terdiri dari biaya bahan bakar, biaya pengemasan, biaya penyusutan, biaya pengangkutan, dan biaya pajak. Sementara itu, Nilai output adalah merupakan harga pasar dari biji kopi untuk setiap bahan baku yang digunakan dalam pengolahan. Dengan melakukan perkalian antara harga output dengan faktor konversi didapatkan nilai output untuk setiap $1 \mathrm{~kg}$ biji kopi pada kemasan alumunium foil sebesar Rp. 36.480 sedangkan untuk kemasan biasa adalah sebesar 30.400. Lebih lanjut, nilai tambah diperoleh dengan mengurangkan harga bahan baku dan sumbangan input lain terhadap nilai output. Nilai tambah dari proses pengolahan biji kopi menjadi kopi bubukk kemasan alumunium foil adalah sebesar Rp. 10.035, artinya bahwa setiap $1 \mathrm{~kg}$ biji kopi yang diolah menjadi kopi bubuk akan menciptakan nilai tambah sebesar Rp. 10.035 per kg. Sedangkan untuk kemasan biasa didapatkan nilai tambah sebesar 8.065 artinya bahwa setiap $1 \mathrm{~kg}$ biji kopi yang diolah menjadi kopi bubuk akan menciptakan nilai tambah sebesar Rp. 8.065 per kg. Nilai tambah tersebut masih merupakan nilai tambah kotor karena mengandung pendapatan tenaga kerja untuk kemasan alumunium foil sebesar 4.435 dan kemasan biasa 1.350. Dengan persentase pendapatan tenaga kerja kemasan alumunium foil terhadap nilai tambah sebesar 44,19 persen dan kemasan biasa sebesar 16,73. pendapatan tenaga kerja merupakan pendapatan yang diterima tenaga kerja untuk setiap kemasan alumunium foil sebesar Rp. 4.435 dan kemasan biasa sebesar 1.350 dari setiap pengolahan satu kilogram biji kopi menjadi kopi bubuk. Dengan rasio nilai tambah untuk kemasan alumunium foil sebesar 27,50 dan kemasan biasa sebesar 26,52.

Besarnya keuntungan kemasan alumunium foil yang diperoleh dari proses 
pengolahan biji kopi ini adalah Rp. 6.015 per $\mathrm{kg}$ dengan persentase tingkat keuntungan rata-rata sebesar 16,27 persen dari nilai output. Sedangkan untuk kemasan biasa tingkat keuntungan yang didapat sebesar 6.961 per $\mathrm{kg}$ dengan persentase sebesar 22,60. Keuntungan ini merupakan selisih dari nilai tambah dengan imbalan tenaga kerja, dimana keuntungan ini merupakan keuntungan bersih yang diterima pengolahan biji kopi. Jadi tingkat keuntungan ini merupakan keuntungan per satu kilogram biji kopi menjadi kopi bubuk bagi pengelolah kopi bubuk Aroma.

Dari hasil analisis nilai tambah ini juga diperoleh informasi marjin dari pengolahan kopi bubuk yaitu selisih antara output dengan harga bahan baku. Untuk kopi bubuk kemasan alumunium foil marjin total yang diperoleh sebesar $\mathrm{Rp}$. 16,480 per $\mathrm{kg}$. Marjin ini terdiri dari imbalan tenaga kerja, modal atau sumbangan input lain dari keuntungan pengusaha. Dari marjin tersebut proporsi untuk tenaga kerja sebesar 26,91 persen, artinya dari marjin sebesar 16,480 per $\mathrm{kg}$ biji kopi tersebut didistribusikan untuk tenaga kerja sebesar 26,91 persen. proporsi marjin untuk modal atau input lain sebesar 39,10 persen artinya dari margin sebesar Rp. 16,480 per kg biji kopi didistribusikan untuk sumbangan modal. dan proporsi marjin untuk keuntungan sebesar 33,98 persen artinya dari margin yang diperoleh didistribusikan untuk imbalan keuntungan sebesar 33,98 persen.

Untuk kopi bubuk kemasan biasa marjin total yang diperoleh sebesar Rp. 10.400 per kg. Dari marjin tersebut proporsi untuk tenaga kerja sebesar 12,98 persen. proporsi marjin untuk modal atau input lain sebesar 22,45 persen dan proporsi marjin untuk keuntungan rata-rata sebesar 64.56 persen. Dari sini dapat dilihat bahwa usaha pengolahan kopi bubuk aroma ini telah memperoleh tingkat keuntungan yang cukup besar dari kemasan biasa dibanding kemasan alumunium foil. Tingkat keuntungan ini dapat lebih ditingkatkan lagi dengan menaikan harga jual pada setiap kemasan dan penggunaan input lain.

\section{Analisis Strategi Pemasaran Kopi Bubuk Aroma}

Strategi Produk merupakan strategi yang paling diprioritaskan dalam pemasaran kopi bubuk Aroma ini. Strategi produk terdiri dari Ragam produk, Kualitas, Desain, Merk,Kemasan,Ukuran, pelayanan, dan jaminan. Namun pada penelitian ini alternatif yang dipilih adalah Ukuran produk, kemasan, pelayanan, dan jaminan. Hal ini dikarenakan karena melihat hal yang pertama sekali dilihat oleh konsumen saat pembelian adalah pada kemasan. Sedangkan faktor yang 
mendasari alternatif tersebut adalah Modal, Ketersediaan Teknologi, dan Skala usaha perusahaan. Untuk lebih jelasnya beberapa kriteria yang mempengaruhi strategi produk kopi bubuk aroma adalah sebagai berikut :

\section{Modal}

Modal adalah sesuatu yang digunakan untuk menjalankan suatu perusahaan. Modal ini biasanya berupa uang atau tenaga (keahlian). Seluruh kegiatan perusahaan selalu berhubungan dengan usaha untuk memperoleh dana dan menggunakan dana tersebut secara efektif dan efisien. Untuk setiap efektifitas yang dilakukan tentunya memerlukam pembiayaan yang bersumber dari pemodalan. Modal kerja yang tidak cukup akan membuat perusahaan tidak dapat menjalankan aktivitasnya secara optimal. Dengan adanya modal maka perusahaan dapat mengembangkan usahanya dengan menambah jenis ukuran kemasan, membut ragam jenis kopi, dan memberikan penjaminan produk agar semakin dipercaya oleh konsumennya. Karena itulah modal sangat berpengaruh terhadapa strategi pemasaran kopi bubuk aroma.

\section{Ketersediaan Teknologi}

Ketersediaan teknologi adalah sarana yang menyediakan barang-barang yang diperlukan bagi kelangsungan industri. Teknologi pada masa saat ini sangat membantu kinerja dalam suatu perusahaan karena teknologi mampu menghemat tenaga, biaya, dan juga waktu. Karena itulah teknologi juga berpengaruh terhadap pemilihan alternatif strategi produk kopi bubuk aroma.

\section{Skala Usaha}

Skala usaha merupakan perbandingan antara upah tenaga kerja dengan hasil yang didapatkan agar dapat melihat perkembangan dari suatu perusahaan. Pada agroindustri kopi bubuk aroma ini memperkerjakan 4 orang dari luar keluarga dalam menjalankan usahanya. Bahan baku yang diproses menjadi kopi bubuk adalah $360 \mathrm{~kg} /$ minggu dan menghasilkan kopi bubuk sebesar $276 \mathrm{~kg} /$ minggu. Omset perminggunya $\quad \pm 10.000 .000 \quad /$ minggu. Skala usaha kopi bubuk aroma ini masih tergolong usaha mikro.

\section{Penentuan Alternatif Strategi Produk}

Beberapa alternatif yang mempengaruhi strategi pemasaran kopi bubuk aroma di kota Bengkulu adalah :

\section{Diversifikasi Ukuran}

Diversifikasi ukuran produk adalah Upaya yang dilakukan perusahaan untuk mengusahakan atau memasarkan beberapa produk yang sama atau sejenis tetapi dengan berbagai macam ukuran yang ditawarkan. Dalam rangka yang bertujuan untuk meningkatkan kinerja penjualan dengan menawarkan ukuran sesuai 
kebutuhan konsumen. Dengan adanya diversivikasi ukuran diharapkan nantinya dapat membantu dan memenuhi keinginan konsumen.

\section{Slogan Produk}

Slogan merupakan komunikasi perusahaan terhadap pelanggannya. Kalimat slogan menerangkan produk yang dikemas dalam kata-kata yang unik dan menarik. Slogan bukan merek tetapi suatu perpaduan komitmen untuk membangun dan menimbulkan gambaran yang baik bagi produk ataupun perusahaan. berfungsi untuk mempengaruhi konsumen. Dengan adanya slogan diharapkan dapat menambah keyakinan dan kepercayaan calon kunsumen untuk membeli produk kopi bubuk aroma.

\section{Kombinasi Warna Kemasan}

Warna dalam kemasan dipercaya memiliki pengaruh terhadap emosional pada konsumen, misalnya panjang gelombang tinggi pada warna merah, orange, dan kuning mengarah pada nilai perangsangan yang kuat serta menyebabkan kegembiraan suasana hati (mood). Peran warna berfungsi sebagai media identifikasi dari identitas produk agar konsumen lebih mengenali produk kita. Oleh karena itu direkomendasikan agar warna kemasan sangat sesuai dengan karakter produknya. Dengan kombinasi warna yang menarik diharapkan nantinya akan menambah rasa suka terhadap produk, karena warna mempengaruhi emosional konsumen. Saat ini warna pada kemasan alumunium foil di kemasan kopi bubuk aroma ini terdiri dari hita, merah, dan coklat.

\section{Informasi Produk}

Informasi Produk adalah informasi mengenai produk yang dijelaskan di bungkus kemasan kopi yang bertujuan untuk memberi tahu konsumen mengenai apa saja yang terdapat dalam kopi aroma ini.informasi yang diberikan ini dapat berupa sertifikat halal, BPOM, umur simpan, harga, izin desperindag, pelayanan konsumen, komposisi, nilai gizi dan ukuran. Informasi kehalalan produk sdianggap erpengaruh terhadap pembelian produk karena melihat mayoritas agama dikota bengkulu adalah agama islam. Umur simpan juga membantu untuk memberi tahu konsumen bahwa produk ini ditanggung jaminan umur simpannya oleh kopi bubuk aroma namun jika melewati batas umur yang tersedia industri kopi bubuk aroma ini tidak menjaminny lagi. Semua Informasi juga berpengaruh terhadap strategi pemasaran karena dengan adanya informasi yang lengkap dan jelas akan menambah daya tarik dan kepercayaan jaminan dan bantuan tersendiri bagi konsumen untuk memilih mengkonsumsi produk kopi bubuk aroma.

\section{Ragam Produk}


Ragam produk adalah pilihan berbagai macam produk yang ditawarkan oleh perusahaan. Masih dengan produk yang sama namun dengan kemasan atau rasa yang berbeda. Bentuk kemasan bisa dibuat dalam bentuk kemasan sachet siap jadi yang didalamnya sudah terdapat kopi + gula dan berbagai macam rasa seperti kopi susu, kopi jahe, kopi mocha, dan lainnya. Banyaknya persaingan kopi bubuk di kota bengkulu bahkan nasional membuat usaha kopi lokal harus lebih gencar lagi dalam melalukan perkembangan usahanya. Karena itu ragam produk perlu dilakukan oleh usaha kopi bubuk aroma ini. Gunanya melakukan keragaman produk ini adalah untuk memberikan tawaran rasa yang sesuai dengan kebutuhan dan keinginan konsumen.

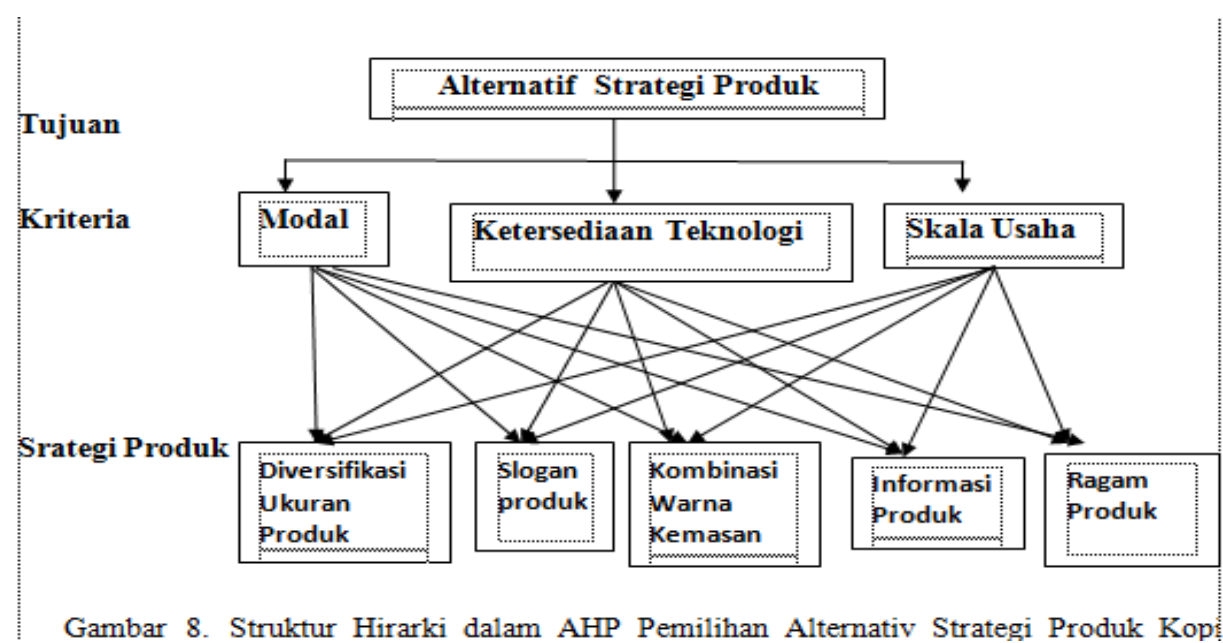

\section{Analisis Penilaian Derajat Kepentingan Kriteria Pemilihan Prioritas Bauran} Pemasaran

Tabel 11. Penilaian Derajat Kepentingan Kriteria

\begin{tabular}{|l|c|c|}
\hline Tujuan & Bobot & Prioritas \\
\hline Kondisi Finansial Perusahaan & 0,334 & 1 \\
SDM & 0,152 & 2 \\
Teknologi Informasi & 0,091 & 6 \\
Sikap Konsumen & 0,143 & 4 \\
Kapasitas Produksi & 0,152 & 3 \\
\hline Kompetitor & 0,128 & 5 \\
\hline Inconsistensy & & 0.01 \\
\hline n-s-
\end{tabular}


Dari hasil analisis yang didapat, bahwa nilai bobot yang paling tinggi untuk kriteria adalah kriteria Kondisi Finansial Perusahaan dengan nilai 0,334 . Prioritas kedua dan ketiga kriteria SDM dan kapasitas produksi yang sama-sama memiliki nilai bobot 0,152 . Prioritas keempat adalah Kriteria Sikap Konsumen dengan nilai bobot 0,143 . Prioritas kelima Kompetitor dengan nilai bobot 0,128 . Selanjutnya prioritas yang paling terendah adalah Teknologi Informasi dengan nilai bobot sebesar 0,091 inconsistensy yang didapat adalah sebesar 0,01 yang menunjukkan bahwa penelitian ini telah terbukti konsisten, karena nilai inconsistensy kriteria pada pemilihan prioritas bauran pemasaran ini adalah $\leq$ 0,1 . Apabila nilai $\geq 0,1$, artinya matriks perbandinga berpasangan ini memberikan pernyataan yang tidak konsisten. Dengan nilai Dari beberapa kriteria pada penelitian ini yang dijadikan prioritas dalam kriteria strategi pemasaran kopi bubuk adalah kriteria kondisi finansial perusahaan. Kondisi finansial perusahaan menjadi prioritas pertama dikarenakan kondisi finansial perusahaan kopi bubuk aroma sangat mempengaruhi pendapatan dari perusahaan. Yang dimaksud dengan kondisi finansial perusahaan adalah kondisi keuangan yang dikelolah oleh perusahaan. Kondisi ini merupakan suatu keadaan dimana perusahaan dapat tetap beroperasi dalam jangka waktu kedepan, kegagalan dalam menghasilkan laba dapat mengancam perusahaan.

Berdasarkan hasil pengolahan secara keseluruhan kriteria pada Tabel 13, telah memenuhi persyaratan rasio inconsistensi dibawah $10 \%$ yakni 1 atau $\leq$ 0,1 berdasarkan tabel 12 diatas dapat diketahui bahwa strategi produk menjadi strategi utama dalam pemilihan strategi pemasaran kopi bubuk aroma dengan bobot sebesar 0,345. Menurut Kotler (2009) produk adalah segala sesuatu yang dapat ditawarkan kepasar untuk mendapatkan perhatian, dibeli, digunakan, atau dikomsumsi yang dapat memuaskan keinginan atau kebutuhan. Strategi produk terdiri dari beberapa alternatif yaitu merek, pengemasan, dan kualitas produk. Strategi produk dianggap sangat perlu untuk dilakukan agar produk kopi bubuk aroma ini dapat menarik perhatian konsumen sehingga diminati untuk dibeli. 


Tabel 13. Nilai bobot Alternaitif Bauran Pemasaran
\begin{tabular}{|l|c|c|}
\hline Alternatif & Bobot & Prioritas \\
\hline Produk & 0,345 & 1 \\
\hline Promosi & 0,239 & 2 \\
\hline Harga & 0,209 & 3 \\
\hline Distribusi & 0,208 & 4 \\
\hline Inconsistensy & & 0,02 \\
\hline
\end{tabular}

Analisis Penilaian Derajat Kepentingan

Kriteria Pemilihan Alternatif Strategi

Produk Pemasaran Kopi Bubuk Aroma

Dari tiga kriteria pada tabel 14, kriteria modal memperoleh prioritas pertama dengan bobot sebesar 0,667 dengan rasio inkonsistensi sebesar 0 yang artinya telah memenuhi syarat $\leq 1$. Dalam menentukan alternatif strategi produk kopi bubuk aroma kriteria modal merupakan aspek yang paling penting. Karena perusahaan membutuhkan modal dalam setiap menjalankan aktifitasnya. Modal merupakan faktor yang sangat penting dalam perusahaan, terutama dalam menjalanan strategi produk. Modal diperlukan untuk membiayai berbagai keperluan usaha seperti biaya surat perizinan,kemasan, ukuran produk, modal kerja, dan membeli barang-brang perlengkapan.

\section{Tabel 14 Hasil Analisis Nilai Bobot Kriteria}

\begin{tabular}{|c|c|c|}
\hline Kriteria & Bobot & Prioritas \\
\hline Modal & 0,667 & 1 \\
\hline Ketersediaan Teknologi & 0,167 & 2 \\
\hline Skala Usaha & 0,167 & 3 \\
\hline Inconsistensy & & 0 \\
\hline
\end{tabular}


Analisis Penilaian Derajat Kepentingan

Pemilihan Alternatif Strategi Produk

\section{Kopi Bubuk Aroma}

\section{a. Kriteria Modal}

Berdasarkan hasil pengolahan dari kriteria Modal, mendiversifikasikan ukuran produk menjadi prioritas utama dalam pemilihan strategi produk kopi bubuk aroma dengan bobot sebesar 0,254. Diversifikasi ukuran produk dianggap sangat perlu untuk dilakukan agar produk kopi bubuk dapat memenuhi keinginan konsumen sesuai dengan kebutuhan dan keinginan mereka.

\section{b. Kriteria Ketersediaan Teknologi}

Berdasarkan kriteria ketersediaan teknologi strategi produk yang diprioritaskan paling utama adalah ragam produk dengan bobot sebesar 0,297. Ragam produk merupakan suatu cara untuk menambah keragaman dari produk kopi bubuk aroma

\section{c. Kriteria Skala Usaha}

Hasil pengolahan secara keseluruhan berdasarkan kriteria skala usaha dalam pmilihan

alternatif strategi produk kopi bubuk aroma telah memehuhi persyaratan inkonsistensi $10 \%$ yaitu 0,02 . Dengan alternatif yang paling diprioritaskan adalah ragam produk dengan bobot 0,345.Berdasarkan hasil pengolahan Alternatif Strategi Produk dengan menggunakan aplikasi

Tabel 16. Hasil Pegolahan Alternatif Strategi

\begin{tabular}{|c|c|c|c|c|}
\hline Kriteria & Alternatif & Bobot & Prioritas & Inconsistensy \\
\hline \multirow[t]{5}{*}{ Modal } & $\begin{array}{l}\text { Diversifikasi ukuran } \\
\text { produk }\end{array}$ & 0,254 & 1 & \\
\hline & Informasi Produk & 0,234 & 2 & 0,02 \\
\hline & Warna Kemasan & 0,214 & 3 & \\
\hline & Ragam produk & 0,207 & 4 & \\
\hline & Slogan Produk & 0,93 & 5 & \\
\hline \multirow{5}{*}{$\begin{array}{l}\text { Ketersediaan } \\
\text { Teknologi }\end{array}$} & Ragam produk & 0,297 & 1 & \\
\hline & $\begin{array}{l}\text { Diversifikasi ukuran } \\
\text { Produk }\end{array}$ & 0,254 & 2 & 0,03 \\
\hline & Informasi Produk & 0,254 & 3 & \\
\hline & Warna Kemasan & 0.131 & 4 & \\
\hline & Siogan Produk & 0,088 & 5 & \\
\hline \multirow[t]{5}{*}{ Skala Usaha } & Ragam produk & 0,345 & 1 & \\
\hline & $\begin{array}{l}\text { Diversifikasi ukuran } \\
\text { Produk }\end{array}$ & 0,315 & 2 & 0,02 \\
\hline & Informasi Produk & 0,151 & 3 & \\
\hline & Warna Kemasan & 0,110 & 4 & \\
\hline & Slogan Produk & 0,079 & 5 & \\
\hline
\end{tabular}


abel 15. Nilai Bobot Keseluruhan Alternatif Strategi

\begin{tabular}{|c|c|c|}
\hline Alternatif & Bobot & Prioritas \\
\hline Mendiversifikasikan Ukuran Produk & 0,262 & 1 \\
\hline Ragam Produk & 0,239 & 2 \\
\hline Memperjelas Informasi Produk & 0,221 & 3 \\
\hline Warna Kemasan & 0,187 & 4 \\
\hline Slogan Produk & 0,090 & 5 \\
\hline Inconsistensy & & 0,02 \\
\hline
\end{tabular}

Dari hasil pengolahan secara keseluruhan pada Tabel 15, telah memenuhi syarat inconsistensi yaitu 0,02 yang artinya $\leq 0,1$. Apabila dilihat dari tabel diatas, alternatif produk yang mendapatkan prioritas pertama adalah mendiversifikasikan ukuran produk, dengan bobot nilai sebesar 0,262. Dalam hal ini diversifikasi ukuran produk menjadi prioritas pertama. Dengan adanya diversifikasi ukuran produk dapat membantu konsumen untuk lebih memilih berbagai macam pilihan ukuran produk yang sesuai dengan kebutuhan mereka. Pada usaha kopi bubuk aroma ini telah memiliki berbagai macam ukuran produk seperti 250 gr,100 gr, 50 gr, dan 25 gr. Sebaiknya perusahaan ini menambah ukurannya seperti $1 \mathrm{~kg}$ dan 500 gr agar ukuran produknya lebih banyak pilihan.

\section{KESIMPULAN}

Dari proses pengolahan data dan analisis yang telah dilakukan, maka dapat diambil kesimpulan sebagi berikut :
1. Dalam nilai tambah kopi bubuk aroma, dengan menggunakan analisis nilai tambah hayami dapat diambil kebijakan bahwa biji kopi akan memiliki nilai jual lebih tinggi setelah diolah menjadi kopi bubuk dari pada dijual berbentuk biji perkilonya. Capaian peningkatan nilai tambah yang diperoleh pada proses ini untuk kemasan biasa adalah sebesar 8.065 dengan rasio nilai tambah sebesar $26,52 \%$ sedangkan nilai tambah untuk plastik alumunium foil sebesar 10.035 dengan rasio nilai tambah sebesar $27,50 \%$.

2. Strategi pemasaran untuk produk kopi bubuk Aroma yang menjadi prioritas pertama adalah strategi produk dengan bobot 0,345 . Prioritas kedua terdapat pada strategi promosi dengan bobot 0,239. prioritas ketiga terdapat pada strategi Harga dengan bobot 0,209 dan prioritas keempat pada strategi distribusi dengan bobot 0,208 .

3. Untuk strategi produk modal menjadi prioritas yang paling diutamakan dengan 
bobot sebesar 0,667. sedangkan yang menjadi prioritas untuk alternatif produk adalah mendeversifikasikan ukuran produk dengan bobot sebesar 0,262.

\section{DAFTAR PUSTAKA}

Dinas Perindustrian dan Perdaganangan. 2015. Daftar Hasil Pemuktahiran Data Industri Kecil Dan Menengah (IKM) Kota Bengkulu. Dinas Perindustrian dan Perdagangan Kota Bengkulu.
Kotler, Kevin Lane Keller. 2009. Manajemen Pemasaran. Jilid kedua. Edisi ketigabelas. Alih Bahasa:Bob Sabran. Jakarta:Erlangga.

Maimun, 2009. Skripsi Analisis Pendapatan Usahatani dan Nilai Tambah Saluran Pemasaran Kopi Arabika Organik dan Non Organik (Studi Kasus Pengolahan Bubuk Kopi Ulee Karang di Banda Aceh.Fakultas Pertanian. Institut Pertanian Bogor.

Tarigan, R. 2004. Ekonomi Regional. Jakarta : Bumi Askara. 